Prepared in cooperation with the Oklahoma Water Resources Board

\title{
Mean Annual Runoff and Annual Runoff Variability Map for Oklahoma, 1940-2007
}

By S. Jerrod Smith and Elise M. Sherrod

Pamphlet to accompany

Scientific Investigations Map 3482 


\section{U.S. Geological Survey, Reston, Virginia: 2021}

For more information on the USGS - the Federal source for science about the Earth, its natural and living resources, natural hazards, and the environment—visit https://www.usgs.gov or call 1-888-ASK-USGS.

For an overview of USGS information products, including maps, imagery, and publications, visit https://store.usgs.gov/.

Any use of trade, firm, or product names is for descriptive purposes only and does not imply endorsement by the U.S. Government.

Although this information product, for the most part, is in the public domain, it also may contain copyrighted materials as noted in the text. Permission to reproduce copyrighted items must be secured from the copyright owner.

Suggested citation:

Smith, S.J., and Sherrod, E.M., 2021, Mean annual runoff and annual runoff variability map for Oklahoma, 1940-2007: U.S. Geological Survey Scientific Investigations Map 3482, 1 sheet, scale 1:100,000, 10-p. pamphlet, https://doi.org/ 10.3133/sim3482.

Associated data for this publication:

Smith, S.J., and Sherrod, E.M., 2021, Data release for mean annual runoff and annual runoff variability map for Oklahoma, 1940-2007: U.S. Geological Survey data release, https://doi.org/10.5066/P9SG5ZD0.

ISSN 2329-132X (online) 


\section{Acknowledgments}

The project documented in this report was conducted in cooperation with the Oklahoma Water Resources Board (OWRB) as part of the U.S. Geological Survey (USGS) Cooperative Water Program. The authors acknowledge the contributions of many OWRB and USGS staff on this project. The authors thank the OWRB for support on this project, especially Assistant Division Chief (Planning and Management Division) Christopher Neel, who helped with defining study objectives and deliverables, and Matt Cogburn, who reviewed the report and the associated data release.

The authors express gratitude to USGS employees Natalie Gillard, Cory Russell, Shana Mashburn, Jeff East, John Gordon, and Tom Burley, who performed detailed technical reviews on this report and the associated data release. The authors acknowledge and appreciate the professionalism, experience, and dedication of these helpful and resourceful colleagues. 



\section{Contents}

Acknowledgments ……...................................................................................................................

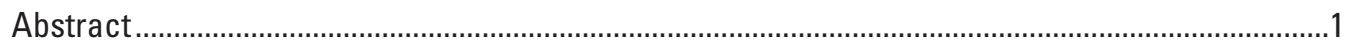

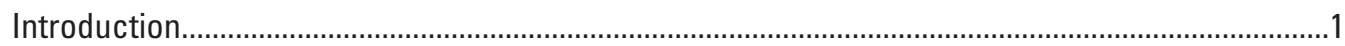

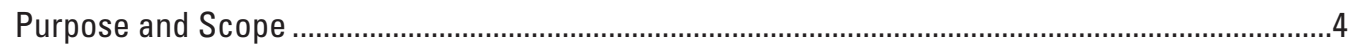

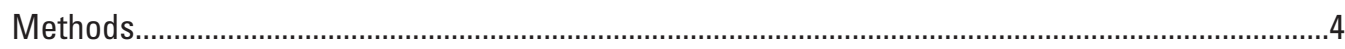

Characteristics and Limitations of the Mean Annual Runoff and Annual Runoff

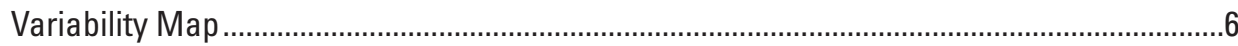

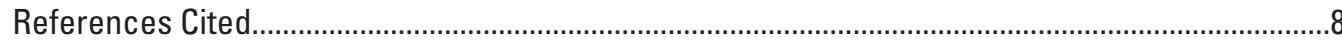

\section{Figures}

1. Photograph depicting the mountainous terrain in southeastern Oklahoma ......................2

2. Graphs showing annual mean precipitation, dry and wet periods, and mean annual precipitation, and number of active streamgages, Oklahoma, 1895-2020.............3

3. Map showing mean annual runoff and annual runoff variability for Oklahoma, 1940-2007 .https://doi.org/10.3133/sim3482

4. Graphs showing relations between mean annual runoff values from this study and mean annual runoff values interpolated from Langbein (1949), Busby (1966), and Gebert and others (1987).......

\section{Conversion Factors}

U.S. customary units to International System of Units

\begin{tabular}{|c|c|c|}
\hline Multiply & By & To obtain \\
\hline \multicolumn{3}{|c|}{ Length } \\
\hline inch (in.) & 2.54 & centimeter $(\mathrm{cm})$ \\
\hline inch (in.) & 25.4 & millimeter $(\mathrm{mm})$ \\
\hline foot $(\mathrm{ft})$ & 0.3048 & meter $(\mathrm{m})$ \\
\hline mile (mi) & 1.609 & kilometer $(\mathrm{km})$ \\
\hline \multicolumn{3}{|c|}{ Area } \\
\hline acre & 4,047 & square meter $\left(\mathrm{m}^{2}\right)$ \\
\hline acre & 0.4047 & hectare (ha) \\
\hline acre & 0.4047 & square hectometer $\left(\mathrm{hm}^{2}\right)$ \\
\hline acre & 0.004047 & square kilometer $\left(\mathrm{km}^{2}\right)$ \\
\hline square mile $\left(\mathrm{mi}^{2}\right)$ & 259.0 & hectare (ha) \\
\hline square mile $\left(\mathrm{mi}^{2}\right)$ & 2.590 & square kilometer $\left(\mathrm{km}^{2}\right)$ \\
\hline \multicolumn{3}{|c|}{ Flow rate } \\
\hline cubic foot per second $\left(\mathrm{ft}^{3} / \mathrm{s}\right)$ & 0.02832 & cubic meter per second $\left(\mathrm{m}^{3} / \mathrm{s}\right)$ \\
\hline inch per year (in/yr) & 25.4 & millimeter per year $(\mathrm{mm} / \mathrm{yr})$ \\
\hline \multicolumn{3}{|c|}{ Hydraulic gradient } \\
\hline foot per mile $(\mathrm{ft} / \mathrm{mi})$ & 0.1894 & meter per kilometer $(\mathrm{m} / \mathrm{km})$ \\
\hline
\end{tabular}




\section{Datum}

Vertical coordinate information is referenced to the North American Vertical Datum of 1988 (NAVD 88).

Horizontal coordinate information is referenced to the North American Datum of 1983 (NAD 83).

Altitude, as used in this report, refers to distance above the vertical datum.

\section{Abbreviations}

$\begin{array}{ll}\text { HUC8 } & \text { 8-digit hydrologic unit } \\ \text { HUC12 } & \text { 12-digit hydrologic unit } \\ \text { OWRB } & \text { Oklahoma Water Resources Board } \\ Q_{20} & \text { 20-percent streamflow-duration statistic } \\ Q_{80} & \text { 80-percent streamflow-duration statistic } \\ \bar{Q} & \text { mean annual streamflow } \\ Q_{\text {var }} & \text { annual streamflow variability } \\ \text { USGS } & \text { U.S. Geological Survey }\end{array}$




\title{
Mean Annual Runoff and Annual Runoff Variability Map for Oklahoma, 1940-2007
}

\author{
By S. Jerrod Smith ${ }^{1}$ and Elise M. Sherrod ${ }^{2}$
}

\section{Abstract}

Hydrologic records used to create previously published maps depicting mean annual runoff are biased to a relatively dry period in Oklahoma history that was dominated by droughts. Therefore, the U.S. Geological Survey, in cooperation with the Oklahoma Water Resources Board, developed an updated mean annual runoff and annual runoff variability map for Oklahoma and parts of adjacent States. The updated map, which is based on mean-annual-streamflow regression equations developed from available streamgage data through 2007 , is assumed to be representative of the long-term mean annual runoff conditions. The map covers all 69 8-digit hydrologic units with at least 1 square mile of area in Oklahoma; those 8-digit hydrologic units contain 2,870 12-digit hydrologic units that provided the geographic framework for the analysis described in this report. Although parts of adjacent States are included in the study area, this report is primarily focused on providing a map of mean annual runoff and annual runoff variability for Oklahoma.

The mean annual runoff increased from less than 0.25 inch per year in the Panhandle of northwestern Oklahoma to more than 30 inches per year in the mountainous terrain of southeastern Oklahoma. The orientation and pattern of mean annual runoff contours in this report were comparable to those of previously published map reports. The annual runoff variability, or the difference between the 80-percent and 20-percent streamflow-duration statistics, increased from less than 0.25 inch per year in the Panhandle of northwestern Oklahoma to more than 40 inches per year in the mountainous terrain of southeastern Oklahoma. The annual runoff variability data were similar in orientation and pattern to the mean annual runoff contours; annual runoff variability generally increased proportionally with increasing mean annual runoff. The annual runoff variability was also greatest, therefore, in the mountainous terrain of southeastern Oklahoma.

The mean annual runoff and annual runoff variability were calculated at sampled points representing the outlets of 12-digit hydrologic units, so the map in this report is most representative of runoff conditions in rural, unregulated

\footnotetext{
${ }^{1}$ U.S. Geological Survey.
}

${ }^{2}$ Oklahoma Water Resources Board. drainage basins at the 12-digit hydrologic-unit scale. The map was developed by using regression equations formulated on streamgage data for the entire period of record through 2007 , but those equations are biased to the period 1940-2007 when streamgages became more numerous and distributed across Oklahoma. Therefore, the map is likely most representative of runoff conditions during the period 1940-2007. Because runoff is a function of climate variables that can change over time, caution is warranted when using the information in this report to project mean annual runoff and annual runoff variability conditions beyond 2007.

\section{Introduction}

The Oklahoma Water Resources Board (OWRB) has jurisdictional authority over the appropriation of surfacewater resources in Oklahoma and issues surface-water permits using the doctrine of prior appropriation (Oklahoma Statutes § 82-105.2 [Oklahoma State Legislature, 2021a]; Oklahoma Statutes § 82-105.13 [Oklahoma State Legislature, 2021b]; Oklahoma Administrative Code Title 785:20 [OWRB, 2021a]). Evaluation of applications for regular stream water permits includes analyses of existing uses and available surface water upstream and downstream from the proposed diversion point(s). Existing uses include permitted use, pending applications, normal storage in Natural Resources Conservation Service ponds under OWRB jurisdiction, established reservoir dependable yields (less existing permitted use from those yields), water designated for navigation, and estimated domestic use. To prevent over-appropriation, the amount of water subject to approval during the permit process is limited by the unappropriated water available at a specific diversion location, use(s) identified on the permit application with present or future need, and the type of permit requested. For applications requiring transportation and use of water outside of the stream system where the proposed diversion point is located, availability of water for future needs within the stream system of origin is also evaluated (OWRB, 2021b). Determination of unappropriated water available for surface-water permits from reservoirs, lakes, or ponds requires additional, separate methodologies. 
The OWRB uses computations of mean annual runoff, mean annual streamflow, or nearby streamgage measurements to estimate the amount of surface water available for allocation. Among other resources, the OWRB has used a 1:7,500,000-scale U.S. map of mean annual runoff for the period 1951-80 (Gebert and others, 1987) to estimate the amount of surface water available for allocation. Gebert and others (1987) is the most recent in a series of contour maps of mean annual runoff for the United States that includes Langbein (1949) for the period 1921-45 and Busby (1966) for the period 1931-60, among others. In computational terms, runoff is the net discharge into a stream from surface-water and groundwater sources minus losses to evapotranspiration (Gebert and others, 1987). The Gebert and others (1987) map, using this definition, expressed mean annual runoff as a mean rate of annual precipitation (in inches per year) over the drainage area of gaged streams. Mean annual runoff for Oklahoma, according to that map, generally increased from northwest to southeast, ranging from less than 0.2 inch per year (in/yr) in the high plains of northwestern Oklahoma (the Panhandle) to greater than $20 \mathrm{in} / \mathrm{yr}$ in the mountainous terrain of southeastern Oklahoma (fig. 1). The Gebert and others (1987) map incorporated data from about 100 streamgages in Oklahoma that met minimum record length and regulation criteria; those criteria were not explicitly stated in that publication, however. Similar maps by Langbein (1949) and Busby (1966), which incorporated data from fewer streamgages, are also used for some comparisons in this report.

Hydrologic records used to create previously published maps depicting mean annual runoff are biased to a relatively dry period in Oklahoma history that was dominated by droughts, the most severe of which were the 1929-41 ("Dust Bowl," Egan, 2006) drought and the 1952-56 drought (fig. 2A; Shivers and Andrews, 2013). Therefore, the U.S. Geological Survey (USGS), in cooperation with the OWRB, developed an updated mean annual runoff and annual runoff variability map for 1940-2007 for Oklahoma and parts of adjacent States. The data used to make the updated mean annual runoff and annual runoff variability map were documented and published (with Federal Geographic Data Committee [1998] formatted metadata) in a USGS data release (Smith and Sherrod, 2021).

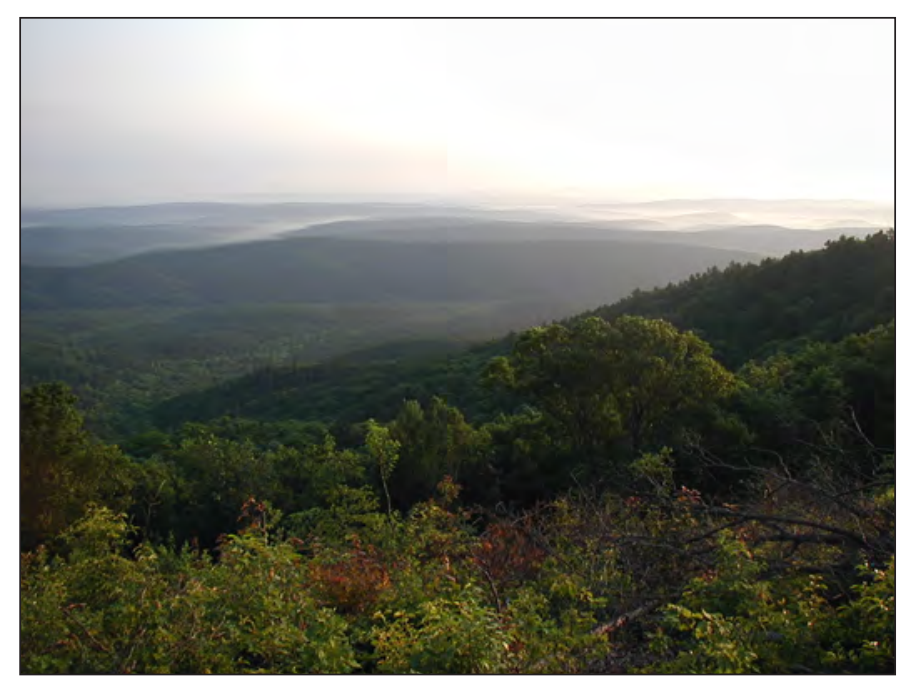

Figure 1. Mountainous terrain in southeastern Oklahoma. Photograph by S. Jerrod Smith, U.S. Geological Survey, June 12, 2005. 


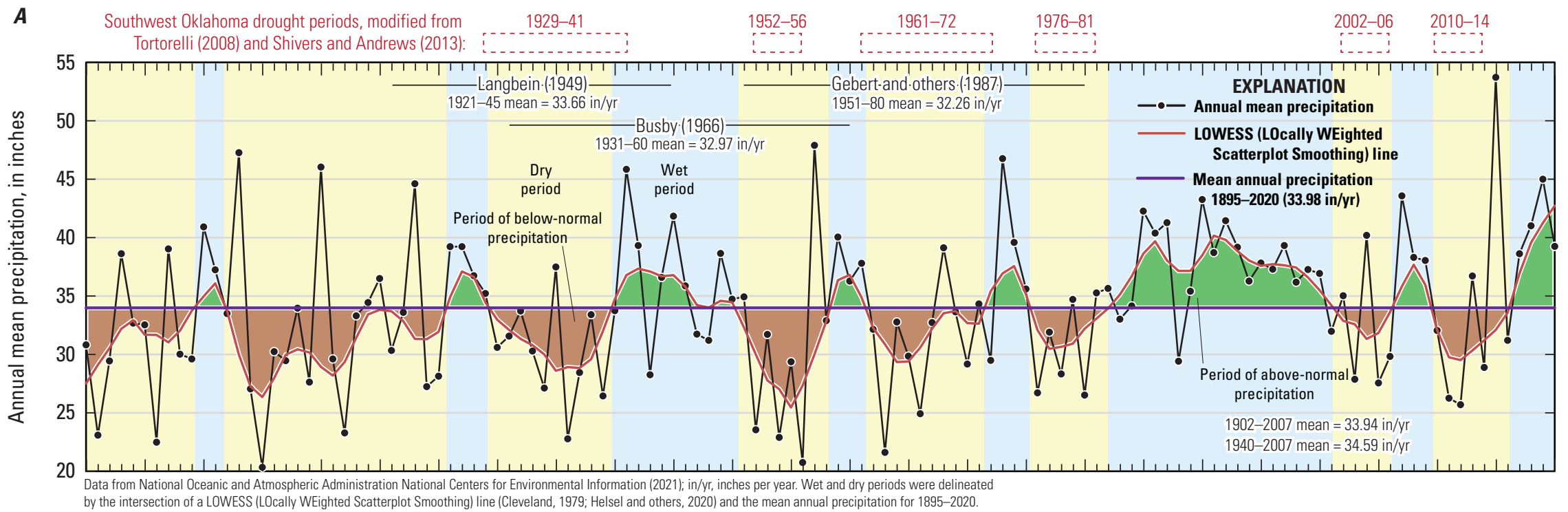

$B$

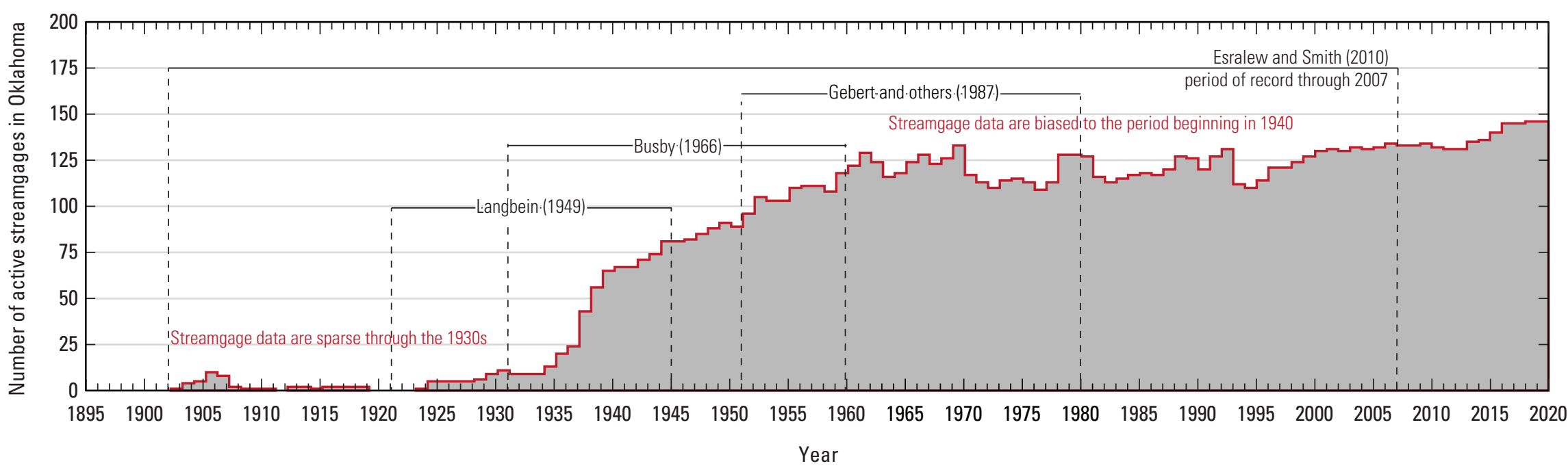

Data from U.S. Geological Survey (2021a). Although most of the streamgages used by Esralew and Smith (2010) were in Oklahoma, some streamgages were in neighboring States and are not represented in this graph.

Figure 2. $A$, Annual mean precipitation, dry and wet periods, and mean annual precipitation, and $B$, number of active streamgages, 0klahoma, 1895-2020. 


\section{Purpose and Scope}

This report describes an updated mean annual runoff and annual runoff variability map for Oklahoma. The updated map, which is based on mean-annual-streamflow regression equations developed from available streamgage data through 2007 as summarized by Lewis and Esralew (2009), is assumed to be representative of the long-term mean annual runoff conditions. Differences between the map in this report and previously published mean annual runoff maps for Oklahoma are explained. Although parts of adjacent States were included in the study area, this report is primarily focused on providing a map of mean annual runoff and annual runoff variability for Oklahoma.

\section{Methods}

A mean annual runoff map was prepared at a resolution that could be used for surface-water permitting in ungaged drainage basins and was accompanied by an assessment of annual runoff variability. The map and companion data release by Smith and Sherrod (2021) cover all 69 8-digit hydrologic units (HUC8s; USGS, 2021e) with at least 1 square mile ( $\left.\mathrm{mi}^{2}\right)$ of area in Oklahoma (figure 3, on sheet 1, available for download at https://doi.org/10.3133/sim3482); those HUC8s contain 2,870 12-digit hydrologic units (HUC12s; not shown on fig. 3) that provided the geographic framework for the analysis described in this report.

To facilitate comparisons between the updated runoff map in this report and previously published maps, the map plates from Langbein (1949), Busby (1966), and Gebert and others (1987) were georeferenced. The relevant contour data in and around the study area were then digitized and interpolated to a 1-kilometer $(\mathrm{km})$ raster for the study area by using the ArcGIS Topo to Raster tool (Esri, 2021e). Interpolated point values for comparison were obtained by using the ArcGIS Extract Multi Values to Points tool (Esri, 2021d).

The methods used in this report differed from those of Gebert and others (1987) and were based on regional regression equations from Esralew and Smith (2010) and streamgage records through 2007 (summarized in Lewis and Esralew, 2009). Esralew and Smith (2010) used data from about 230 streamgages in Oklahoma and parts of adjacent States with at least 10 years of unregulated streamflow record (USGS, 2021a) to develop mean annual streamflow $(\bar{Q})$ equations for ungaged streams draining unregulated, rural basins in Oklahoma. Those equations were developed by using regional regression methods on selected drainage basin characteristics (such as contributing drainage area and mean annual precipitation; USGS, 2021d) that were found to be the most reliable predictors of $\bar{Q}$ and other selected streamflow statistics at the selected streamgages. By using the appropriate regional regression equations, $\bar{Q}$ can be efficiently estimated for any point on any stream represented in the USGS StreamStats web application for Oklahoma (Smith and Esralew, 2010; Ries and others, 2017). The $\bar{Q}$, when divided by contributing drainage area and converted (using the appropriate conversion factor) to units of inches per year, is equivalent to the mean annual runoff as defined by Gebert and others (1987).

Esralew and Smith (2010) also developed regional regression equations for the 20-percent $\left(Q_{20}\right.$; wetter) and 80-percent $\left(Q_{80}\right.$; drier) streamflow-duration statistics. The $Q_{20}$ and $Q_{80}$ statistics report the streamflows that are equaled or exceeded 20 percent and 80 percent of the time, respectively, and together indicate a range of streamflows during the majority (60 percent) of the year. The $Q_{20}$ and $Q_{80}$ statistics also can be calculated in the USGS StreamStats web application for Oklahoma, except for locations on the largest streams (Arkansas, Canadian, Cimarron, Red, Neosho, and Verdigris Rivers), which have headwaters outside of the study area. However, these excepted streams are monitored by multiple streamgages with long periods of record that can be used to calculate more accurate mean annual runoff data.

The Esralew and Smith (2010) regression regions (fig. 3) were mostly delineated along major drainage basin boundaries to coincide with U.S. Environmental Protection Agency ecoregions (Woods and others, 2005) that divide Oklahoma into areas with similar soil permeability and forested percentage. For region 1 (fig. 3), which covers most of western Oklahoma excluding the Panhandle, the $\bar{Q}, Q_{80}$, and $Q_{20}$, in cubic feet per second, can be estimated as

$$
\begin{gathered}
\bar{Q}=65.7 \times([\text { contda }] / 424)^{0.83} \times([\operatorname{prc} 610] / 15.2)^{7.50} \\
Q_{80}=7.15 \times([\text { contda }] / 424)^{0.81} \times([\text { elev }] / 1,721)^{-4.49} \times([\operatorname{prc} 610] / 15.2)^{2.78}
\end{gathered}
$$




$$
Q_{20}=59.5 \times([\text { contda }] / 424)^{0.85} \times([\mathrm{elev}] / 1,721)^{-0.80} \times([\operatorname{prc} 610] / 15.2)^{4.81}
$$

where

contda is the contributing drainage area, in square miles,

prc610 is the mean annual June-October precipitation for the period 1971-2000 at the drainage basin outlet, in inches per year, and

elev is the mean basin elevation, in feet above the North American Vertical Datum of 1988.

For region 2 (fig. 3), which covers parts of south-central and north-eastern Oklahoma, the $\bar{Q}, Q_{80}$, and $Q_{20}$, in cubic feet per second, can be estimated as

$$
\begin{gathered}
\bar{Q}=193 \times([\text { contda }] / 323)^{0.91} \times([\operatorname{prc} 610] / 19.3)^{3.35} \\
Q_{80}=7.01 \times([\text { contda }] / 323)^{2.19} \times([\text { csl10_85fm }] / 6.04)^{2.26} \times([\text { outelev }] / 783)^{4.93} \times([\text { prc 115] }] / 22.0)^{14.7}-0.1 \\
Q_{20}=142 \times([\text { contda }] / 323)^{1.09} \times([\text { csl10_85fm }] / 6.04)^{0.23} \times([\text { outelev }] / 783)^{1.04} \times([\text { prc } 115] / 22.0)^{5.92}
\end{gathered}
$$

where

contda is the contributing drainage area, in square miles,

prc610 is the mean annual June-October precipitation for the period 1971-2000 at the drainage basin outlet, in inches per year,

csl10_85fm is the 10-85 stream slope, in feet per mile,

outelev is the elevation at the drainage basin outlet, in feet above the North American Vertical Datum of 1988, and

prc115 is the mean annual November-May precipitation for the period 1971-2000 at the drainage basin outlet, in inches per year.

For region 3 (fig. 3), which covers central, eastern, and southeastern Oklahoma, the $\bar{Q}, Q_{80}$, and $Q_{20}$, in cubic feet per second, can be estimated as

$$
\begin{gathered}
\bar{Q}=203 \times([\text { contda }] / 203)^{1.02 \times} \times([\text { prcout }] / 47.8)^{4.51} \\
Q_{80}=9.39 \times([\text { contda }] / 203)^{1.32 \times([\text { canopy }] / 40.8)^{-2.07} \times([\text { elev }] / 1,010)^{3.24} \times([\text { prcout }] / 47.8)^{11.7}-0.1} \\
Q_{20}=197.8 \times([\text { contda }] / 203)^{1.09} \times([\text { canopy }] / 40.8)^{-0.11 \times([\text { elev }] / 1,010)^{0.74} \times([\text { prcout }] / 47.8)^{6.27}}
\end{gathered}
$$

where

contda is the contributing drainage area, in square miles,

prcout is the mean annual precipitation for the period 1971-2000 at the drainage basin outlet, in inches per year,

canopy is the percent canopy cover of the drainage basin, and

elev is the mean basin elevation, in feet above the North American Vertical Datum of 1988.

Equations for $\bar{Q}, Q_{80}$, and $Q_{20}$ were not developed for the Oklahoma Panhandle (region 0, fig. 3) because most streams in that region remain dry most of the year (Smith and others, 2015). For the purposes of this report, however, the equations from region 1 also were applied to region 0 because the regions had comparable climate and land cover conditions. The $\bar{Q}$ sometimes is outside the range of $Q_{80}-Q_{20}$ at a given location. This can occur because (1) the streamflow distribution at a location is strongly skewed toward high (flood) values and (2) the $\bar{Q}$ equations were developed independently using different explanatory variables (basin characteristics) than the $Q_{80}$ and $Q_{20}$ equations. About 63 percent of the HUC12 outlet points analyzed in this report had a regression-calculated $\bar{Q}$ value greater than the regression-calculated $Q_{20}$ value. In comparison, about 45 percent of the streamgages analyzed by Lewis and Esralew (2009) had a $\bar{Q}$ value greater than the $Q_{20}$ value. The regression-calculated $Q_{80}$ also can be larger than the regression-calculated $Q_{20}$ (a statistical impossibility) at some locations because the $Q_{80}$ and $Q_{20}$ equations were developed independently. HUC12 outlet points exhibiting this inversion (22 of 2,610 HUC12 outlet points [not 
counting the 260 outlet points located on excepted streams]) were excluded from further analysis; all but 2 of those points were on the most downstream reach of the North Canadian River, which, in terms of contributing drainage area, was the largest stream (not counting excepted streams) in the study area. For the remaining HUC12 outlet points, annual streamflow variability $\left(Q_{\text {var }}\right)$, in cubic feet per second, was estimated as

$$
Q_{\text {var }}=Q_{20}-Q_{80}
$$

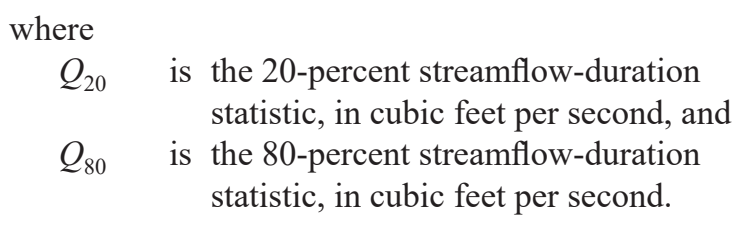

This statistic approximates the interquartile range of streamflow and was assumed to approximate the range of natural variation in annual streamflow that might be expected from year to year at a location. $\bar{Q}$ and $Q_{\text {var }}$ were divided by contda and converted (using the constant 13.5837 inch-square mile-second per cubic foot-year) to units of inches per year to obtain mean annual runoff and annual runoff variability values that were comparable with previously published contour maps of mean annual runoff:

$$
\text { mean annual runoff }=\bar{Q} / \text { contda } \times 13.5837
$$

annual runoff variability $=Q_{\text {var }} /$ contda $\times 13.5837$

The mean annual runoff and annual runoff variability map in this report was interpreted from sampled points representing the outlets of 2,870 HUC12s. Use of these outlets ensured that sampled points were (1) evenly spaced because the HUC12s were delineated to have comparable areas in the range of 10,000-40,000 acres (15.6-62.5 $\mathrm{mi}^{2}$; USGS and U.S. Department of Agriculture, Natural Resources Conservation Service, 2013), (2) distributed across streams of various sizes in proportion to their frequency in the landscape, and (3) tied into the Watershed Boundary Dataset and National Hydrography Dataset networks for attribution purposes (for example, drainage basin and stream naming; Horizon Systems Corporation, 2010).

The HUC12 outlet points were manually aligned with the Oklahoma StreamStats stream grid (USGS, 2021c) and processed sequentially by the StreamStats web services (USGS, 2021b) by using a Python 2.7.18 (Python Software Foundation, 2021) script (included in Smith and Sherrod [2021]) to manage outlet point submission and save resulting basin characteristic values. Those basin-characteristic (explanatory-variable) values were then used in equations 1-9 to calculate $\bar{Q}, Q_{80}$, and $Q_{20}$ statistics for each HUC12 outlet point. The set of regional regression equations associated with the location of the outlet point was used even when the outlet point's drainage basin spanned multiple regions; $\bar{Q}$, $Q_{80}$, and $Q_{20}$ statistics were not weighted by the proportion of the drainage area in each region. However, the drainage basins that spanned multiple regions mostly were limited to the largest drainage basins, which are monitored by long-period streamgages.

The mean annual runoff and annual runoff variability values at HUC12 outlet points were calculated by using equations 11-12 and interpolated to a 1-km raster (only the annual runoff variability raster is shown on fig. 3) by using the ArcGIS Topo to Raster tool (Esri, 2021e). The ArcGIS Contour tool (Esri, $2021 \mathrm{~b}$ ) then was used to generate 0.25 -in/yr contours from the interpolated mean annual runoff raster. The raster and derived contours were then clipped to an analysis area formed by a $20-\mathrm{km}$ buffer of the 69 selected HUC8s by using the ArcGIS Extract by Mask tool (Esri, 2021c) and ArcGIS Clip tool (Esri, 2021a), respectively. The 0.25 -in/yr contour interval was shown only in western Oklahoma where this level of precision is necessary because of the small magnitude of values; a $1.0-\mathrm{in} / \mathrm{yr}$ contour interval was shown for the rest of Oklahoma to simplify the map (fig. 3). Enclosed contours (for example, depressions) less than 50 miles in length also were omitted to improve map readability. The full uncensored set of 0.25 -in/ yr-interval contours are available in the data release (Smith and Sherrod, 2021) that is associated with this report.

\section{Characteristics and Limitations of the Mean Annual Runoff and Annual Runoff Variability Map}

The mean annual runoff (shown as contour lines on fig. 3) increased from less than $0.25 \mathrm{in} / \mathrm{yr}$ in the Panhandle of northwestern Oklahoma to more than $30 \mathrm{in} / \mathrm{yr}$ in the mountainous terrain of southeastern Oklahoma. The orientation and pattern of mean annual runoff contours in this report were comparable to those of Langbein (1949), Busby (1966), and Gebert and others (1987), but the values were, on average, about 19.4, 8.6, and 9.6 percent greater than interpolated values from those respective reports (fig. 4). The greater mean annual runoff values documented in this report as compared to previously published mean annual runoff values are likely the result of the relatively dry periods analyzed by Langbein (1949), Busby (1966), and Gebert and others (1987) as compared to the relatively wet period of record through 2007 used by Esralew and Smith (2010) to formulate regional regression equations (fig. 2). During the early period of streamgaging in Oklahoma from about 1900 through 1939, streamgages in Oklahoma were sparse (fig. 2). The regression equations formulated on streamgage data by Esralew and Smith (2010) are therefore biased in favor of the data collected during 1940-2007 when streamgages became progressively more numerous and distributed across Oklahoma and therefore likely more representative of runoff conditions during 1940-2007 than the 
runoff conditions during 1900-1939. Some records used in Langbein (1949), Busby (1966), and Gebert and others (1987) were adjusted for the effects of irrigation practices or were extended by using correlation procedures. Records designated by Esralew and Smith (2010) as affected by irrigation were not used to formulate the regional regression equations used in this report, and extension of records was unnecessary given the longer period of record and greater number of streamgages available to Esralew and Smith (2010).
The annual runoff variability increased from less than $0.25 \mathrm{in} / \mathrm{yr}$ in the Panhandle of northwestern Oklahoma to more than $40 \mathrm{in} / \mathrm{yr}$ in the mountainous terrain of southeastern Oklahoma. The annual runoff variability data were similar in orientation and pattern to the mean annual runoff contours; annual runoff variability (shown as shaded areas on fig. 3) generally increased proportionally with increasing mean annual runoff. The annual runoff variability was also greatest, therefore, in the mountainous terrain of southeastern
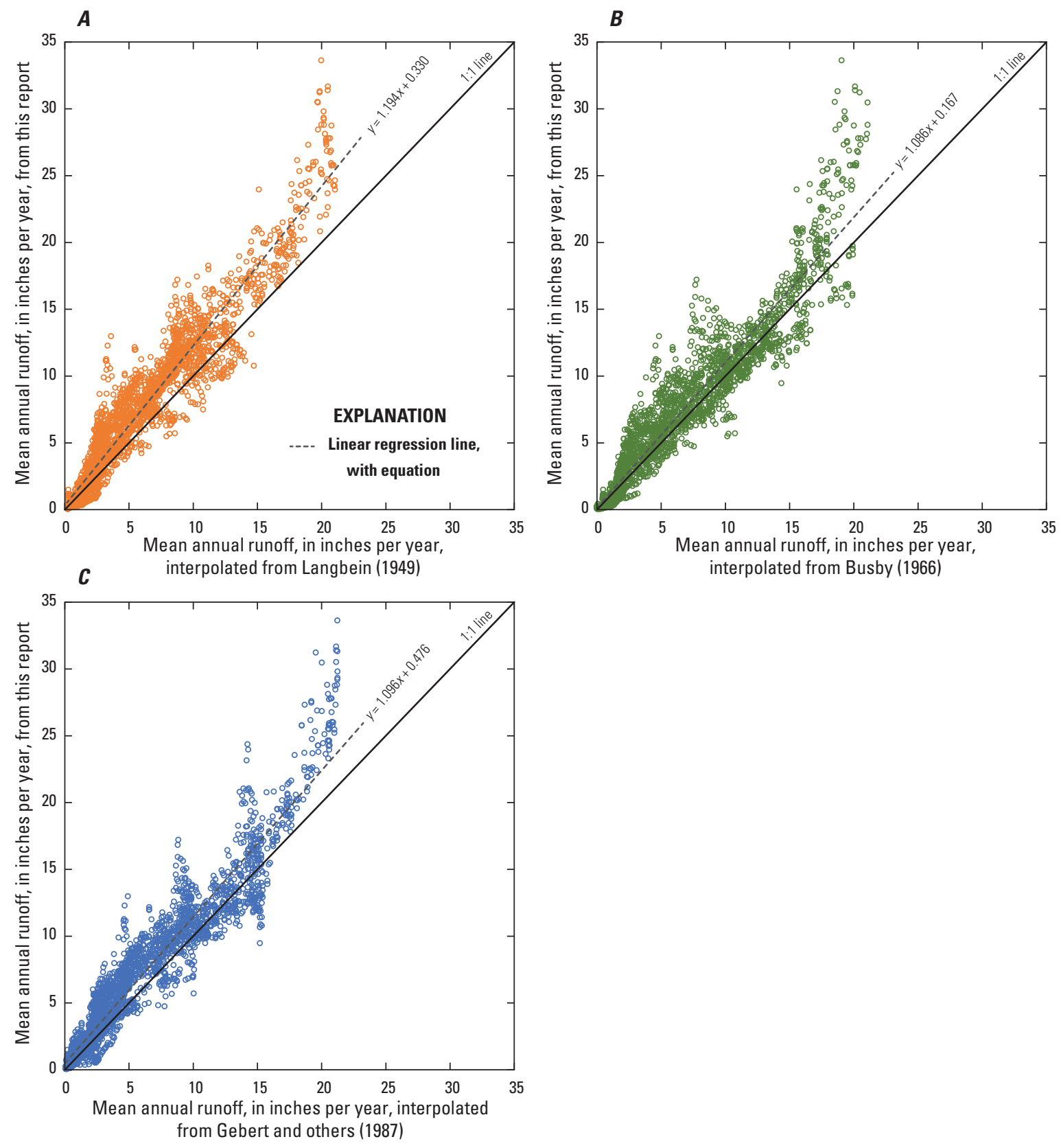

Figure 4. Relations between mean annual runoff values from this study (calculated by using regression equations from Esralew and Smith [2010]) and mean annual runoff values interpolated from $A$, Langbein (1949), B, Busby (1966), and $C$, Gebert and others (1987). 
Oklahoma (figs. 1 and 3) that promotes precipitation and runoff (U.S. Department of Agriculture, 1999; National Severe Storms Laboratory, 2021).

The mean annual runoff and annual runoff variability were calculated at sampled points representing the outlets of HUC12s, so the map in this report is most representative of runoff conditions in rural, unregulated drainage basins at the HUC12 or 10-digit hydrologic-unit (HUC10) scale; 408 (14.2 percent) of the 2,870 HUC12 outlets used to make the map were also 10-digit hydrologic-unit outlets. As drainage basins increase in size, they are more likely to be (1) regulated by large dams or irrigation practices, (2) augmented by substantial groundwater contributions, and (3) monitored by streamgages with long periods of record. Methods for computing or estimating runoff for gaged basins generally rely on the streamgage record when sufficient data are available. For an ungaged stream reach between two streamgages, the drainage-area-ratio method (Esralew and Smith, 2010), rather than the map in this report, can be used to obtain a more accurate mean annual runoff or annual runoff variability estimate. The drainage-area-ratio method, which assumes that streamflow generally increases in proportion to increased drainage area, equates the ratio of streamflow at two stream locations to the ratio of the respective drainage areas. The map was developed by using regression equations (Esralew and Smith, 2010) formulated on streamgage data for the entire period of record through 2007 (Lewis and Esralew, 2009), but those equations are biased to the period 1940-2007 when streamgages became more numerous and distributed across Oklahoma (fig. 2).

Therefore, the map is likely most representative of runoff conditions during the period 1940-2007. Because runoff is a function of climate variables that can change over time, caution is warranted when using the information in this report to project mean annual runoff and annual runoff variability conditions beyond 2007.

\section{References Cited}

Busby, M.W., 1966, Annual runoff in the conterminous United States: U.S. Geological Survey Hydrologic Investigations Atlas HA-212, 1 sheet, scale 1:7,500,000, accessed September 27, 2021, at https://doi.org/10.3133/ha212.

Cleveland, W.S., 1979, Robust locally weighted regression and smoothing scatterplots: Journal of the American Statistical Association, v. 74, no. 368, p. 829-836, accessed September 27, 2021, at https://doi.org/10.1080/ 01621459.1979 .10481038$.

Egan, T., 2006, The worst hard time: New York, Houghton Mifflin Company, $340 \mathrm{p}$.
Esralew, R.A., and Smith, S.J., 2010, Methods for estimating flow-duration and annual mean-flow statistics for ungaged streams in Oklahoma: U.S. Geological Survey Scientific Investigations Report 2009-5267, 131 p., accessed September 27, 2021, at https://doi.org/10.3133/sir20095267.

Esri, 2021a, ArcGIS for Desktop help-Clip tool: Esri web page, accessed May 6, 2021, at https://desktop.arcgis.com/ en/arcmap/10.7/tools/analysis-toolbox/clip.htm.

Esri, 2021b, ArcGIS for Desktop help - Contour tool: Esri web page, accessed May 6, 2021, at https://desktop.arcgis. com/en/arcmap/10.7/tools/3d-analyst-toolbox/contour.htm.

Esri, 2021c, ArcGIS for Desktop help-Extract by Mask tool: Esri web page, accessed May 6, 2021, at https://desktop. arcgis.com/en/arcmap/10.7/tools/spatial-analyst-toolbox/ extract-by-mask.htm.

Esri, 2021d, ArcGIS for Desktop help-Extract Multi Values to Points tool: Esri web page, accessed May 6, 2021, at https://desktop.arcgis.com/en/arcmap/10.7/tools/spatialanalyst-toolbox/extract-multi-values-to-points.htm.

Esri, 2021e, ArcGIS for Desktop help-Topo to Raster tool: Esri web page, accessed May 6, 2021, at https://desktop. arcgis.com/en/arcmap/10.7/tools/spatial-analyst-toolbox/ topo-to-raster.htm.

Federal Geographic Data Committee, 1998, Content standard for digital geospatial metadata (revised June 1998): Washington, D.C., Federal Geographic Data Committee FGDC-STD-001-1998, 78 p., accessed September 27, 2021, at https://www.fgdc.gov/standards/projects/metadata/basemetadata/v2_0698.pdf.

Gebert, W.A., Graczyk, D.J., and Krug, W.R., 1987, Average annual runoff in the United States, 1951-80: U.S. Geological Survey Hydrologic Investigations Atlas HA-710, 1 sheet, scale 1:7,500,000, accessed September 27, 2021, at https://doi.org/10.3133/ha710.]

Helsel, D.R., Hirsch, R.M., Ryberg, K.R., Archfield, S.A., and Gilroy, E.J., 2020, Statistical methods in water resources: U.S. Geological Survey Techniques and Methods, book 4, chapter A3, 458 p., accessed September 27, 2021, at https://doi.org/10.3133/tm4A3. [Supersedes USGS Techniques of Water-Resources Investigations, book 4, chapter A3, version 1.1, released in 2002.]

Horizon Systems Corporation, 2010, National Hydrography Dataset Plus (NHDPlus) Version 1: Horizon Systems Corporation, accessed November 1, 2010, at https://nhdplus.com/NHDPlus/.

Langbein, W.B., 1949, Annual runoff in the United States: U.S. Geological Survey Circular 52, 14 p., 1 pl., accessed September 27, 2021, at https://doi.org/10.3133/cir52. 
Lewis, J.M., and Esralew, R.A., 2009, Statistical summaries of streamflow in and near Oklahoma through 2007: U.S. Geological Survey Scientific Investigations Report 2009-5135, 36 p., accessed September 27, 2021, at https://doi.org/10.3133/sir20095135.

National Oceanic and Atmospheric Administration National Centers for Environmental Information, 2021, Climate at a glance-Divisional time series, accessed January 20, 2021, at https://www.ncdc.noaa.gov/cag/statewide/time-series/ 34/pcp/12/12/1895-2020?base_prd=true\&begbaseyear= 1895 endbaseyear $=2000$.

National Severe Storms Laboratory, 2021, Severe weather 101-Floods, accessed September 13, 2021, at https:// www.nssl.noaa.gov/education/svrwx101/floods/.

Oklahoma State Legislature, 2021a, Right to use water, Domestic use, Priorities, chap. 105, section 2 of Waters and water rights - Oklahoma Statutes, title 82, accessed October 19, 2021, at https://oksenate.gov/sites/default/files/ 2019-12/os82.pdf.

Oklahoma State Legislature, 2021b, Seasonal, temporary, term and provisional permits - Limited quantity stream water permits, chap. 105, section 13 of Waters and water rightsOklahoma Statutes, title 82, accessed October 19, 2021, at https://oksenate.gov/sites/default/files/2019-12/os82.pdf.

Oklahoma Water Resources Board [OWRB], 2021a, Appropriation and use of stream water, chap. 20 of Oklahoma Administrative Code, title 785-Oklahoma Water Resources Board, accessed October 19, 2021, at https://casetext.com/regulation/oklahoma-administrativecode/title-785-oklahoma-water-resources-board.

Oklahoma Water Resources Board [OWRB], 2021b, Oklahoma water law-The water use permitting process, accessed September 15, 2021, at https://www.owrb.ok.gov/ news/news2/pdf_news2/pres/WaterLawandRights.pdf.

Python Software Foundation, 2021, Python 2.7.18, accessed April 1, 2021, at https://www.python.org/downloads/ release/python-2718/.

Ries, K.G., III, Newson, J.K., Smith, M.J., Guthrie, J.D., Steeves, P.A., Haluska, T.L., Kolb, K.R., Thompson, R.F., Santoro, R.D., and Vraga, H.W., 2017, StreamStats, version 4: U.S. Geological Survey Fact Sheet 2017-3046, 4 p., accessed September 27, 2021, at https://doi.org/10.3133/ fs20173046.

Shivers, M.J., and Andrews, W.J., 2013, Hydrologic drought of water year 2011 compared to four major drought periods of the 20th century in Oklahoma: U.S. Geological Survey Scientific Investigations Report 2013-5018, 52 p., accessed July 5, 2020, at https://doi.org/10.3133/sir20135018.
Smith, S.J., and Esralew, R.A., 2010, StreamStats in Oklahoma-Drainage-basin characteristics and peak-flow frequency statistics for ungaged streams: U.S. Geological Survey Scientific Investigations Report 2009-5255, 59 p., accessed September 27, 2021, at https://doi.org/10.3133/ sir20095255.

Smith, S.J., Lewis, J.M., and Graves, G.M., 2015, Methods for estimating the magnitude and frequency of peak streamflows at ungaged sites in and near the Oklahoma Panhandle: U.S. Geological Survey Scientific Investigations Report 2015-5134, 35 p., accessed September 27, 2021, at https://doi.org/10.3133/sir20155134.

Smith, S.J., and Sherrod, E.M., 2021, Data release for mean annual runoff and annual runoff variability map for Oklahoma, 1940-2007: U.S. Geological Survey data release, https://doi.org/10.5066/P9SG5ZDO.

Tortorelli, R.L., 2008, Hydrologic drought of water year 2006 compared with four major drought periods of the 20th century in Oklahoma: U.S. Geological Survey Scientific Investigations Report 2008-5199, 46 p., accessed June 5, 2020, at https://doi.org/10.3133/sir20085199.

U.S. Census Bureau, 2000, TIGER/line shapefiles and TIGER/ line files: U.S. Census Bureau online database, accessed December 15, 2014, at https://www.census.gov/geo/ mapsdata/data/tiger-line.html.

U.S. Department of Agriculture, 1999, Ozark-Ouachita Highlands assessment—Aquatic conditions: Asheville, N.C., U.S. Department of Agriculture, Forest Service, Southern Research Station General Technical Report SRS-33, 317 p., accessed September 27, 2021, at https://doi.org/10.2737/SRS-GTR-33.

U.S. Geological Survey, [USGS], 2015, The National Map - National Elevation Dataset: U.S. Geological Survey National Geospatial Program website, accessed January 2015 at https://ned.usgs.gov/index.html.

U.S. Geological Survey, [USGS], 2021a, Gages through the ages, accessed September 27, 2021, at https://labs. waterdata.usgs.gov/visualizations/gages-through-the-ages/ index.html\#/.

U.S. Geological Survey, [USGS], 2021b, USGS StreamStats Service documentation, accessed January 24, 2021, at https://streamstats.usgs.gov/docs/streamstatsservices/\#/.

U.S. Geological Survey, [USGS], 2021c, USGS StreamStats stream grid download, accessed January 24, 2021, at https:// streamstatsags.cr.usgs.gov/StreamGrids/.

U.S. Geological Survey, [USGS], 2021d, USGS StreamStats support-Oklahoma, accessed January 24, 2021, at https:// streamstats.freshdesk.com/support/solutions/articles/ 9000055601-oklahoma. 
U.S. Geological Survey, [USGS], 2021e, Hydrologic unit maps-What are hydrologic units?: U.S. Geological Survey web page, accessed January 24, 2021, at https://water. usgs.gov/GIS/huc.html.

U.S. Geological Survey [USGS] and U.S. Department of Agriculture, Natural Resources Conservation Service, 2013, Federal standards and procedures for the national Watershed Boundary Dataset (WBD) (4th ed.): U.S.

Geological Survey Techniques and Methods, book 11, chap. A3, 63 p., accessed September 27, 2021, at https://doi.org/ 10.3133/tm11a3.
Woods, A.J., Omernik, J.M., Butler, D.R., Ford, J.G., Henley, J.E., Hoagland, B.W., Arndt, D.S., and Moran, B.C., 2005, Ecoregions of Oklahoma: Reston, Virginia, U.S. Geological Survey (scale 1:1,250,000), accessed September 27, 2021, at https://www.epa.gov/eco-research/ecoregion-downloadfiles-state-region-6.

For more information about this publication, contact

Director, Oklahoma-Texas Water Science Center

U.S. Geological Survey

1505 Ferguson Lane

Austin, Texas 78754-4501

For additional information, visit

https://www.usgs.gov/centers/ot-water/

Publishing support provided by

Lafayette Publishing Service Center 



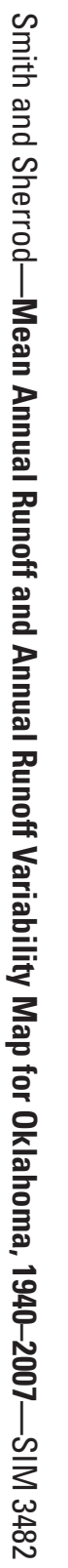

